\title{
Simplified technique for identification of the aerobic spore-forming bacteria by phenotype
}

Danylo Zabolotny Institute of Microbiology and Virology, National Academy of Sciences of Ukraine, 154 Zabolotny Str., Kyiv 03143, Ukraine

\author{
O. N. Reva, I. B. Sorokulova and V. V. Smirnov \\ Author for correspondence: Valery V. Smirnov. Tel: +380 44 2661179. Fax: +380 442662379. \\ e-mail: Smirnov@imv.kiev.ua
}

\begin{abstract}
The use of modern research approaches of genetics, biochemistry and molecular biology has led to progress in bacterial taxonomy. Systematic study of the aerobic spore-forming bacteria has resulted in the realignment of the genus Bacillus into several new genera. In the meantime, the identification process has become more difficult for the non-specialist in Bacillus taxonomy. This paper presents a key for the simplified phenotypic identification of the mesophilic, aerobic, spore-forming bacteria belonging to the genera Bacillus, Paenibacillus, Brevibacillus, Aneurinibacillus, Geobacillus and Virgibacillus. A total of 81 species were included and 115 morphological and physiological tests were analysed for their discriminative efficiency. This key is practical for rough but quick identification of aerobic spore-forming bacteria isolated from nature. Such preliminary identification will be helpful for the selection of reference strains and methods for more precise identification using the newest techniques. The reliability of the proposed identification key was tested on 100 cultures from the Ukrainian Collection of Microorganisms. The developed identification key is represented in interactive mode on a website (http://www/imv.kiev.ua/key/).
\end{abstract}

Keywords: identification, phenotype, spore-forming bacteria

\section{INTRODUCTION}

Aerobic spore-forming bacteria represent a major microflora in many natural biotopes, where they play an important role in ecosystem development; they are able to transform many chemical compounds, including industrial pollutants. Therefore, the investigation of these micro-organisms is highly important for microbiologists dealing with ecological studies and environment protection. The identification of aerobic spore-forming bacteria was always a difficult task, but has recently become almost impossible to the nonspecialist in the field of bacillus systematics and identification. Many of the up-to-date, sophisticated genetic and biochemical methods that have permitted improvements in bacilli taxonomy are too difficult for routine use. A prominent trend of current microbiological practice is the identification of microorganisms based only on $16 \mathrm{~S}$ rRNA sequences, which provides rather limited resolution (Schloter et al., 2000; Stackebrandt \& Goebel, 1994). Uncritical use of results of $16 \mathrm{~S}$ rRNA gene comparison can lead to

Abbreviation: VP, Voges-Proskauer. incorrect identification and, more dangerously, to incorrect association of DNA sequences in a genetic database with particular species, which will multiply the error many times. It would be useful to supply scientists with a method to check quickly whether their strains identified by $16 \mathrm{~S}$ rRNA agree with the corresponding species characteristics.

In recent years, twelve new genera of aerobic sporeforming bacteria have been proposed: Alicyclobacillus (Wisotzkey et al., 1992), Amphibacillus (Niimura et al., 1990), Aneurinibacillus and Brevibacillus (Shida et al., 1996), Filobacillus (Schlesner et al., 2001), Geobacillus (Nazina et al., 2001), Halobacillus (Spring et al., 1996), Paenibacillus (Ash et al., 1993), Virgibacillus (Heyndrickx et al., 1998), Gracilibacillus and Salibacillus (Wainø et al., 1999) and Ureibacillus (Fortina et al., 2001). Many species and genus names used routinely in the current scientific literature are not present in Bergey's Manual of Systematic Bacteriology (Claus \& Berkeley, 1986). This situation causes difficulties in identification of any bacillus. In addition, some authors have described new species based on significantly different sets of physiological and morphological characters, adding to the problem of 
Table 1. Strains used in this study

Strains were obtained from the following culture collections: ATCC, American Type Culture Collection, Manassas, VA, USA; DSM, German Collection of Microorganisms and Cell Cultures, Braunschweig, Germany; UCM, Ukrainian Collection of Microorganisms, Kyiv, Ukraine; VKM, All-Russian Collection of Microorganisms, Pushchino, Russia. Strain accession numbers are from the UCM or are our work numbers unless otherwise stated.

\begin{tabular}{|c|c|}
\hline Species & Strains \\
\hline Bacillus badius & UCM B-5820 \\
\hline Bacillus cereus & UCM B-5650 $\left(\right.$ DSM $\left.31^{\mathrm{T}}\right) ; 5652 ; 5653 ; 5655 ; 5656 ; 5659 ; 5671 ; 5673$ \\
\hline Bacillus cereus var. mycoides & UCM B-5674 \\
\hline Bacillus circulans & UCM B-5841 (ATCC 9966); 5845 (VKM B-729) \\
\hline Bacillus coagulans & $\mathrm{UCM} B-5850^{\mathrm{T}}\left(\mathrm{DSM} 1^{\mathrm{T}}\right)$ \\
\hline 'Bacillus endophyticus' & UCM B- $5715 ; 5908 ; 5910 ; 5912$ \\
\hline 'Bacillus entomocidus' & UCM B-5900 (ATCC 19268) \\
\hline Bacillus lentus & UCM B-5906 $6^{\mathrm{T}}\left(\mathrm{DSM} 9^{\mathrm{T}}\right)$ \\
\hline Bacillus licheniformis & UCM B-5501 ${ }^{\mathrm{T}}\left(\mathrm{DSM} 13^{\mathrm{T}}\right) ; 5502 ; 5503 ; 5506 ; 5508 ; 5510 ; 5511 ; 5512 ; 5513 ; 5514$ \\
\hline 'Bacillus longissimus' & UCM B-5880 (DSM 352) \\
\hline Bacillus megaterium & UCM B-5723 (ATCC 9885); 5714; 5716; 5718; 5719 \\
\hline Bacillus pumilus & UCM B-5604 $\left(\mathrm{DSM} 27^{\mathrm{T}}\right) ; 5601 ; 5602 ; 5609 ; 5610 ; 5617$ \\
\hline Bacillus sphaericus & UCM B-5901 $\left(\mathrm{DSM} 28^{\mathrm{T}}\right) ; 5902$ \\
\hline Bacillus subtilis & $\begin{array}{l}\text { UCM B-5006 }^{\mathrm{T}}\left(\mathrm{DSM} 10^{\mathrm{T}}\right) ; 5001(\mathrm{ATCC} 10774) ; 5002 ; 5007 ; 5008 ; 5009 ; 5010 ; 5012 ; 5014 ; \\
5016 ; 5017 ; 5018 ; 5019 ; 5021 ; 5029 ; 5036 ; 5042 ; 5044 ; 5050 ; 5071 ; 5074 ; 5075 ; 5121 ; \\
5111 ; 5112 ; 5113 ; 5127\end{array}$ \\
\hline Bacillus thuringiensis var. sotto & UCM B-5680 $\left(\right.$ ATCC $\left.19270^{\mathrm{T}}\right)$ \\
\hline Bacillus sp. & $\begin{array}{l}\text { UCM B-5530; 5843; 5844; 5715; 5908; 5910; 5911; 9DT; 7-91D; 76D; 103D; 106D; } \\
\text { 107D; 108D; 109D; 111D; 115D; 119D; 121D; } 1 \mathrm{r} ; 2 \mathrm{r}\end{array}$ \\
\hline Brevibacillus brevis & UCM B-5830 $\left(\mathrm{DSM} 30^{\mathrm{T}}\right)$ \\
\hline Brevibacillus laterosporus & UCM B-5870 $\left(\mathrm{DSM} 25^{\mathrm{T}}\right)$ \\
\hline Paenibacillus alvei & UCM B-5904 \\
\hline Paenibacillus macerans & UCM B-5803 $\left(\mathrm{DSM} 24^{\mathrm{T}}\right) ; 5800$ \\
\hline Paenibacillus polymyxa & UCM B-5760 (DSM 36 $\left.{ }^{\mathrm{T}}\right) ; 5756 ; 5757 ; 5758 ; 5759$ \\
\hline Paenibacillus pulvifaciens & UCM B-5909 (VKM B-748) \\
\hline Virgibacillus pantothenticus & UCM B-5907 (DSM 26) \\
\hline
\end{tabular}

comparing phenotypes. It therefore seemed useful to review and summarize the current taxonomic and identification schemes developed for aerobic sporeforming bacteria. In this review, both approved and newly proposed species names are included. It is, however, beyond the scope of this paper to discuss the worth of the use of any of these taxonomic names. The review is intended to discuss some aspects of the phenotypic heterogeneity of the bacilli and to analyse the suitability of several phenotypic tests for identification of aerobic spore-forming bacteria. Our purpose was to put together the scattered descriptions of all known species of Bacillus and related genera in order to provide a method by which an idea of what an unknown strain could be can be formulated, before using more complicated and expensive methods of investigation. We want to underline that the key proposed below is targeted to the rough identification of aerobic spore-forming micro-organisms, and further detailed identification may be required.

The paper deals with mesophilic spore-forming bacteria growing on nutrient agar at neutral $\mathrm{pH}$ under aerobic conditions at temperatures of $25-45^{\circ} \mathrm{C}$. We have therefore not included in this discussion representatives of such genera as Alicyclobacillus (thermophiles and acidophiles), Amphibacillus and Ureibacillus (alkaliphiles), Halobacillus, Filobacillus, Gracilibacillus and Salibacillus (halotolerant bacteria) and several extremophilic, asporogenous and nutritionally fastidious Bacillus, Geobacillus and Paenibacillus species.

\section{METHODS}

Selection of phenotypic tests for the identification key. Information obtained from the literature concerning 81 species of aerobic spore-forming bacteria characterized by 115 physiological and morphological tests was accumulated and summarized in a database.

A criterion to determine the discriminative efficiency of a test was calculated from the following equation:

$E_{i}=4 \times\left(\bar{q}_{i}\left(1-\bar{q}_{i}\right)-\frac{\sum_{t} q_{i t}\left(1-q_{i t}\right)}{N}\right)$

where $\bar{q}_{i}$ is the ratio of positive responses of test $i$ for all species; $q_{i t}$ is the ratio of positive responses for test $i$ for strains of species $t$; and $N$ is the total number of species in the 
Table 2. Tests ranked by their discriminative efficiency for the identification of aerobic spore-forming bacteria

$E$ represents the efficiency of a test as calculated from the equation given in Methods, whereas $e$ represents the calculated efficiency of a test multiplied by the proportion of species that were characterized by that test.

\begin{tabular}{|c|c|c|c|c|}
\hline \multirow[t]{2}{*}{ Rank } & \multicolumn{2}{|c|}{ Not taking frequency of test use into account } & \multicolumn{2}{|c|}{ Taking frequency of test use into account } \\
\hline & Test & $\boldsymbol{E}$ & Test & $e$ \\
\hline 1 & Resistance to nalidixic acid $\left(32 \mu \mathrm{g} \mathrm{ml}^{-1}\right)$ & $0 \cdot 93$ & Degradation of starch & $0 \cdot 86$ \\
\hline 2 & Resistance to polymyxin $\left(16 \mu \mathrm{g} \mathrm{ml}^{-1}\right)$ & $0 \cdot 91$ & Growth at $50{ }^{\circ} \mathrm{C}$ & $0 \cdot 80$ \\
\hline 3 & Anaerobic growth & $0 \cdot 89$ & Nitrate reduction & $0 \cdot 75$ \\
\hline 4 & Degradation of starch & $0 \cdot 89$ & Sporangium bulging & $0 \cdot 75$ \\
\hline 5 & Degradation of Tween 20 & $0 \cdot 88$ & Anaerobic growth & $0 \cdot 73$ \\
\hline 6 & Growth at $50{ }^{\circ} \mathrm{C}$ & $0 \cdot 87$ & Degradation of casein & $0 \cdot 72$ \\
\hline 7 & Degradation of casein & $0 \cdot 86$ & Growth with $5 \%(\mathrm{w} / \mathrm{v}) \mathrm{NaCl}$ & $0 \cdot 66$ \\
\hline 8 & Acid from L-arabinose & $0 \cdot 85$ & Gelatin liquefaction & $0 \cdot 65$ \\
\hline 9 & Growth with $5 \%(\mathrm{w} / \mathrm{v}) \mathrm{NaCl}$ & $0 \cdot 85$ & Acid from L-arabinose & $0 \cdot 61$ \\
\hline 10 & Oxidase activity & $0 \cdot 85$ & Length of cell $>3 \mu \mathrm{m}$ & $0 \cdot 61$ \\
\hline 11 & Acid from melibiose & $0 \cdot 84$ & Growth at $\mathrm{pH} 6.0$ & $0 \cdot 59$ \\
\hline 12 & Acid from raffinose & $0 \cdot 84$ & Acid from xylose & $0 \cdot 59$ \\
\hline 13 & pH Voges-Proskauer broth $<7$ & $0 \cdot 83$ & Utilization of citrate & $0 \cdot 58$ \\
\hline 14 & Utilization of succinate & $0 \cdot 83$ & Oxidase activity & $0 \cdot 58$ \\
\hline 15 & Acid from mannitol & $0 \cdot 83$ & Voges-Proskauer reaction & $0 \cdot 55$ \\
\hline 16 & Growth at $\mathrm{pH} 6.0$ & $0 \cdot 82$ & Acid from raffinose & $0 \cdot 53$ \\
\hline 17 & Nitrate reduction & $0 \cdot 82$ & Growth at $28^{\circ} \mathrm{C}$ & $0 \cdot 52$ \\
\hline 18 & Acid from xylose & $0 \cdot 82$ & Acid from salicin & $0 \cdot 52$ \\
\hline 19 & Acid from salicin & $0 \cdot 81$ & Acid from galactose & $0 \cdot 51$ \\
\hline 20 & Degradation of Tween 80 & $0 \cdot 81$ & Acid from lactose & $0 \cdot 48$ \\
\hline
\end{tabular}

database. Of all possible tests, the most efficient would be a test for which the value of $E_{\mathrm{i}}$ is 1 , in the case where a given number of species is divided into two equal groups (positive and negative by this test) with no variable responses. If all of the species are positive or negative by this test or if the variability of the test between several species is the same as that within this species, the value of $E_{\mathrm{i}}$ is zero.

Bacterial strains. The identification test that we developed was tested on strains isolated from different ecological niches and contained in the Ukrainian Collection of Microorganisms (UCM). These strains are represented in Table 1 by their catalogue number (if available) or by work numbers for fresh isolates.

Phenotypic characterization. Strains were tested as described by Claus \& Berkeley (1986) and Gordon et al. (1973) by using the following characteristics: cellular and spore morphology; catalase and oxidase activity; Voges-Proskauer (VP) test; nitrate reduction to nitrite; anaerobic growth; gas production from nitrate and glucose; starch, urea and casein degradation; gelatin liquefaction; acid production from glucose, galactose, lactose, mannose, mannitol, salicin and fructose; citrate utilization; decomposition of tyrosine; arginine dihydrolase activity; growth with $5 \%(\mathrm{w} / \mathrm{v}) \mathrm{NaCl}$ and with $0 \cdot 001 \%(\mathrm{w} / \mathrm{v})$ lysozyme.

Genotyping. Ribotyping was performed as described by Aquino de Muro \& Priest (1993). Arbitrary primer PCR (RAPD typing) was carried out as described by Brousseau et al. (1993). Primer 0955-03 (5'-CCGGCGGCG-3') was used for amplification.

\section{RESULTS AND DISCUSSION}

In Table 2, the phenotypic tests available are shown in order of decreasing discriminative efficiency $(E)$. On the right of the table, the same tests are ranked by the discriminative efficiency multiplied by $n_{\mathrm{t}} / N(e)$, where $n_{\mathrm{t}}$ is the number of species characterized by test $t$ and $N$ is the total number of species in the database. Only the 20 most efficient phenotypic tests from 115 analysed are represented in Table 2. It is therefore clear from this table that the bacilli were divided most efficiently by such tests as resistance to nalidixic acid $\left(32 \mu \mathrm{g} \mathrm{ml}^{-1}\right)$ and to polymyxin $\left(16 \mu \mathrm{g} \mathrm{ml}^{-1}\right)$. However, only 34 species of bacillus were characterized by these tests (Priest et al., 1988), so they are not included in the list of the 20 most efficient tests as ranked by $e$ (Table 2).

The selection of tests for the identification key was based on their discriminative efficiency and their usual application in routine laboratory characterization of aerobic spore-forming micro-organisms. Having set the tests for one level of the key, the discriminative efficiencies of the remaining tests were recalculated for each group obtained. While selecting tests, the correlative independence of any pair of tests was also taken into account. Another goal was to minimize the number of key tests and to choose, if possible, tests that occurred elsewhere in the key, even if they were 


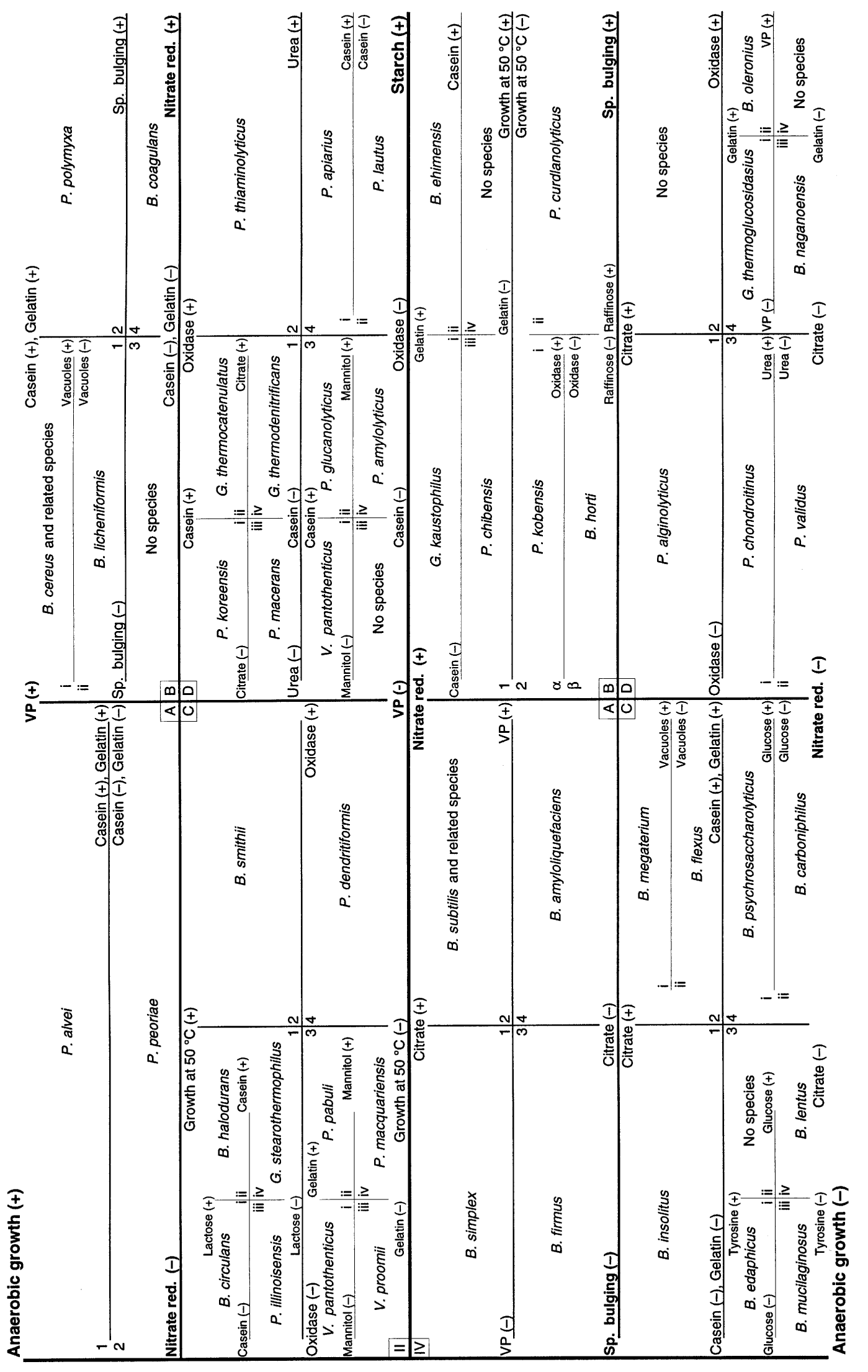




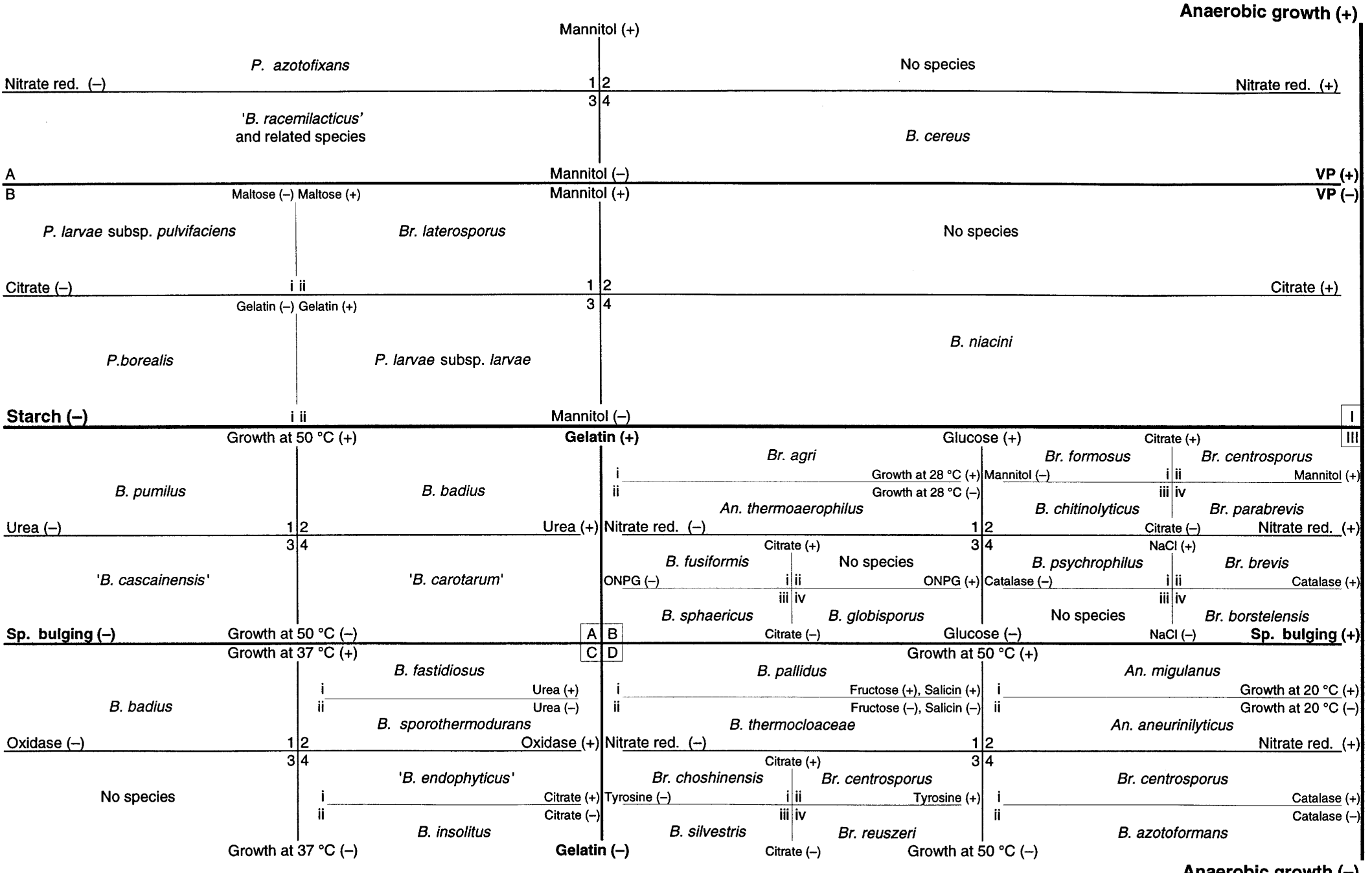

Fig. 1. Key for identification of the aerobic spore-forming bacteria. Genera are abbreviated as: An., Aneurinibacillus; B., Bacillus; Br., Brevibacillus; G., Geobacillus; P., Paenibacillus; V., Virgibacillus. Tests are abbreviated as: Casein, casein degradation; Citrate, citrate utilization; Fructose, fructose fermentation; Galactose, galactose fermentation; Gas, gas production from glucose; Gelatin, gelatin degradation; Glucose, glucose fermentation; Lysozyme, resistance to lysozyme $\left(10 \mu \mathrm{g} \mathrm{ml}^{-1}\right)$; Maltose, maltose fermentation; Mannitol, mannitol fermentation; NaCl, growth with $5 \%$ (w/v) NaCl; Nitrate red., nitrate reduction; ONPG, $\beta$-galactosidase activity detected by o-nitrophenyl $\beta$-D-galactopyranoside degradation; Salicin, salicin fermentation; Sp. bulging, presence of bulging sporangia; Starch, starch degradation; Succinate, succinate utilization; Tyrosine, tyrosine degradation; Urea, urea degradation; Vacuoles, vacuoles in cytoplasm; VP, Voges-Proskauer test. Species names not included in the Approved Lists of Bacterial Names (Skerman et al. 1980) or validly published in IJSB and IJSEM since 1980 are given in quotes. An example of finding a particular species within the key is given as follows: Bacillus sphaericus is a non-starch-hydrolysing, obligately aerobic species (group III) that hydrolyses gelatin with spores in swollen sporangia (subgroup III.B), is negative for glucose fermentation and nitrate reduction (III.B.3) and is negative for citrate utilization and the ONPG test (giving the final address III.3.3.iii). 
slightly less effective. Furthermore, phylogenetic relatedness was not considered as a basis for dividing the organisms into groups. Our only aim was to simplify species identification. The identification key is shown in Fig. 1.

Strains of some species were variable by the tests selected for the key. Such strains are represented in different cells of the scheme (Fig. 1). Thus, strains of Bacillus cereus are variable for starch degradation, so this species is placed in two different cells, I.A.4 and II.B.1.i. Some tests were considered as positive (negative) for a species if the proportion of strains responding positively was over $80 \%$ (did not exceed $20 \%)$.

Group I consists of facultatively anaerobic microorganisms incapable of starch hydrolysis (Fig. 1). It is subdivided further according to the Voges-Proskauer reaction (VP). VP-positive organisms form subgroup I.A and VP-negative organisms form subgroup I.B. Subgroup I.A includes Bacillus cereus, Paenibacillus azotofixans and a group of homolactic acid-fermenting bacteria similar to 'Bacillus racemilacticus' ('Bacillus laevolacticus', 'Bacillus myxolacticus' and 'Bacillus dextrolacticus'). These species were differentiated on the basis of the optical isomer of lactic acid produced; however, they were found to be strains of the same species according to data for 16S rRNA gene sequences (Suzuki \& Yamasato, 1994). Nishikawa et al. (1996) reported that B. cereus strains incapable of starch hydrolysis were frequently producers of the emetic toxin, a cause of food-poisoning outbreaks.

Subgroup I.B includes insect pathogens belonging to the genera Brevibacillus and Paenibacillus, a nicotinate-metabolizing species, Bacillus niacini, and a nitrogen-fixing bacterium, Paenibacillus borealis. Paenibacillus larvae and Paenibacillus pulvifaciens were reclassified as subspecies of $P$. larvae (Heyndrickx et $a l .$, 1996a). Two other species belong to this subgroup, namely Bacillus thermocatenulatus (a thermophile that is distinguished by growth at $50{ }^{\circ} \mathrm{C}$; Golovacheva et al., 1975) and Bacillus pasteurii (an alkaliphile that is recognized by growth at $\mathrm{pH} 9.0$ and high urease activity; Claus \& Berkeley, 1986).

Group II includes facultatively anaerobic, starchhydrolysing representatives of the genus Paenibacillus, thermophilic species of Geobacillus and the Bacillus cereus group, including Bacillus thuringiensis, Bacillus mycoides and Bacillus anthracis. Further identification was based on the following features: VP reaction, nitrate reduction, casein and gelatin hydrolysis, growth at $50{ }^{\circ} \mathrm{C}$, oxidase and urease activities and gas production from glucose. Virgibacillus pantothenticus also appeared in group II; however, the phenotypic patterns provided by different authors for this species were contradictory. Recently, a new species of this genus, Virgibacillus proomii, was described (Heyndrickx et al., 1999). Seemingly, strains of this species are variable for the VP reaction and nitrate reduction.
The species of the Bacillus cereus group are closely related. However, they can be differentiated on the basis of several morphological features and susceptibility to antibiotics (Claus \& Berkeley, 1986; Priest et al., 1988). Recently, two new species of this group have been proposed: Bacillus pseudomycoides (Nakamura, 1998) and Bacillus weihenstephanensis (Lechner et al., 1998).

Group III (obligate aerobes that do not hydrolyse starch) includes species belonging to the genera Bacillus, Brevibacillus and Aneurinibacillus. Gelatin hydrolysis and swollen sporangia are the most effective tests for further differentiation of these microorganisms.

Subgroups III.A and III.C (sporangia are not swollen) include the ubiquitous species Bacillus pumilus and Bacillus badius, a psychrophilic species, Bacillus insolitus, and two rather fastidious species, Bacillus fastidiosus (Claus \& Berkeley, 1986) and Bacillus sporothermodurans (Pettersson et al., 1996). Bacillus insolitus, together with Bacillus globisporus, 'Bacillus aminovorans' and Bacillus marinus, forms a separate phylogenetic group (Rüger, 1983). The phenotypic properties of Bacillus marinus and 'Bacillus aminovorans' were poorly described, so they are not represented in the key.

Swelling of the sporangium is a character peculiar to the genera Brevibacillus and Aneurinibacillus. However, in some strains of Aneurinibacillus, the sporangium can be only slightly swollen or not swollen at all (Heyndrickx et al., 1997). Bacillus galactophilus was reclassified as Brevibacillus agri (Shida et al., 1994). Subgroups III.B and III.D include thermophiles (Bacillus thermocloaceae, Bacillus pallidus, Aneurinibacillus thermoaerophilus), psychrophiles (Bacillus psychrophilus, Bacillus globisporus), Bacillus sphaericus with the closely related species (or subspecies) Bacillus fusiformis, and Bacillus chitinolyticus (Kuroshima et al., 1996). Strains of Bacillus sphaericus could be also distinguished by resistance to streptomycin $\left(16 \mu \mathrm{g} \mathrm{ml}^{-1}\right)$ (Priest et al., 1988) or $30 \mu \mathrm{g}$ per disk (Reva et al., 1995). According to a description of Bacillus thermosphaericus, this species cannot convincingly be distinguished phenotypically from Bacillus thermocloaceae (Andersson et al., 1995).

Group IV encompasses obligatory aerobic, starchhydrolysing bacilli. This group includes species of the genera Bacillus, Paenibacillus and Aneurinibacillus. Nitrate reduction and the presence of swollen sporangia were the most discriminative test markers for further subdivision of this group. The central species of the group is Bacillus subtilis, a ubiquitous micro-organism and type species of the genus Bacillus. Four new species similar to Bacillus subtilis have been proposed: Bacillus amyloliquefaciens (Priest et al., 1987), Bacillus atrophaeus (Nakamura, 1989), Bacillus mojavensis (Roberts et al., 1994) and Bacillus vallismortis (Roberts et al., 1996). Approximately $90 \%$ of Bacillus subtilis strains utilized citrate and $80 \%$ of 
Table 3. Index of species referred to in this paper with their key addresses

\begin{tabular}{|c|c|c|}
\hline Species & Address & Reference \\
\hline Aneurinibacillus aneurinilyticus & III.D.2.ii & Heyndrickx et al. (1997) \\
\hline Aneurinibacillus migulanus & III.D.2.i & Heyndrickx et al. (1997) \\
\hline Aneurinibacillus thermoaerophilus & III.B.1.ii & Meier-Stauffer et al. (1996) \\
\hline Bacillus amyloliquefaciens & IV.A.4 & Priest et al. (1987) \\
\hline Bacillus azotoformans & III.D.4.ii & Seldin et al. (1984) \\
\hline Bacillus badius & III.A.2, III.C.1 & Claus \& Berkeley (1986) \\
\hline Bacillus brevis & see Brevibacillus & Shida et al. (1996) \\
\hline Bacillus carboniphilus & IV.C.4.ii & Fujita et al. (1996) \\
\hline 'Bacillus carotarum' & III.A.4 & Priest et al. (1988) \\
\hline 'Bacillus cascainensis' & III.A. 3 & Priest et al. (1988) \\
\hline Bacillus cereus & II.B.1.i, I.A.4 & Claus \& Berkeley (1986) \\
\hline Bacillus chitinolyticus & III.B.2.iii & Kuroshima et al. (1996) \\
\hline Bacillus circulans & II.C.1.i & Claus \& Berkeley (1986) \\
\hline Bacillus coagulans & II.B.4 & Claus \& Berkeley (1986) \\
\hline Bacillus edaphicus & IV.C.3.i & Shelobolina et al. (1997) \\
\hline Bacillus ehimensis & IV.B.1.ii & Kuroshima et al. (1996) \\
\hline 'Bacillus endophyticus' & III.C.4.i & Reva et al. (2001) \\
\hline Bacillus fastidiosus & III.C.2.i & Claus \& Berkeley (1986) \\
\hline Bacillus firmus & IV.A.3 & Claus \& Berkeley (1986) \\
\hline Bacillus flexus & IV.C.2.ii & Priest et al. (1988) \\
\hline Bacillus fusiformis & III.B.3.i & Priest et al. (1988) \\
\hline Bacillus globisporus & III.B.3.iv & Rüger (1983) \\
\hline Bacillus halodurans & II.C.1.ii & Nielsen et al. (1995) \\
\hline Bacillus horti & IV.B.2.i. $\beta$ & Yumoto et al. (1998) \\
\hline Bacillus insolitus & III.C.4.ii, IV.C.1 & Rüger (1983) \\
\hline Bacillus kaustophilus & see Geobacillus & Nazina et al. (2001) \\
\hline Bacillus laterosporus & see Brevibacillus & Shida et al. (1996) \\
\hline Bacillus lentus & IV.C.3.iv & Claus \& Berkeley (1986) \\
\hline Bacillus licheniformis & II.B.1.ii & Claus \& Berkeley (1986) \\
\hline Bacillus megaterium & IV.C.2.i & Claus \& Berkeley (1986) \\
\hline Bacillus mucilaginosus & IV.C.3.iii & Shelobolina et al. (1997) \\
\hline Bacillus naganoensis & IV.D.4.iii & Tomimura et al. (1990) \\
\hline Bacillus niacini & I.B.4 & Nagel \& Andersen (1991) \\
\hline Bacillus oleronius & IV.D.4.ii & Kuhnigk et al. (1995) \\
\hline Bacillus pallidus & III.D.1.i & Scholz et al. (1987) \\
\hline Bacillus pantothenticus & see Virgibacillus & Heyndrickx et al. (1998) \\
\hline Bacillus psychrophilus & III.B.4.i & Priest et al. (1988) \\
\hline Bacillus psychrosaccharolyticus & IV.C.4.i & Priest et al. (1988) \\
\hline Bacillus pumilus & III.A.1 & Claus \& Berkeley (1986) \\
\hline 'Bacillus racemilacticus' & I.A.3 & Spring et al. (1996) \\
\hline Bacillus silvestris & III.D.3.iii & Rheims et al. (1999) \\
\hline Bacillus simplex & IV.A. 1 & Priest et al. (1988) \\
\hline Bacillus smithii & II.C.2 & Nakamura et al. (1988) \\
\hline Bacillus sphaericus & III.B.3.iii & Claus \& Berkeley (1986) \\
\hline Bacillus sporothermodurans & III.C.2.ii & Pettersson et al. (1996) \\
\hline Bacillus stearothermophilus & see Geobacillus & Nazina et al. (2001) \\
\hline Bacillus subtilis & IV.A. 2 & Claus \& Berkeley (1986) \\
\hline Bacillus thermocatenulatus & see Geobacillus & Nazina et al. (2001) \\
\hline Bacillus thermocloaceae & III.D.1.ii & Demharter \& Hensel (1989) \\
\hline Bacillus thermodenitrificans & see Geobacillus & Nazina et al. (2001) \\
\hline Bacillus thermoglucosidasius & see Geobacillus & Nazina et al. (2001) \\
\hline Brevibacillus agri & III.B.1.i & Nakamura (1993) \\
\hline Brevibacillus borstelensis & III.B.4.iv & Shida et al. (1995) \\
\hline Brevibacillus brevis & III.B.4.ii & Claus \& Berkeley (1986) \\
\hline
\end{tabular}


Table 3 (cont.)

\begin{tabular}{|c|c|c|}
\hline Species & Address & Reference \\
\hline Brevibacillus centrosporus & III.B.2.ii, III.D.4.i, III.D.3.ii & Nakamura (1993) \\
\hline Brevibacillus choshinensis & III.D.3.i & Takagi et al. (1993) \\
\hline Brevibacillus formosus & III.B.2.i & Shida et al. (1995) \\
\hline Brevibacillus laterosporus & I.B.1.ii & Claus \& Berkeley (1986) \\
\hline Brevibacillus parabrevis & III.B.1.iv & Takagi et al. (1993) \\
\hline Brevibacillus reuszeri & III.D.3.iv & Shida et al. (1995) \\
\hline Geobacillus kaustophilus & IV.B.1.i & Priest et al. (1988) \\
\hline Geobacillus stearothermophilus & II.C.1.iv & Claus \& Berkeley (1986) \\
\hline Geobacillus thermocatenulatus & II.D.1.ii & Golovacheva et al. (1975) \\
\hline Geobacillus thermodenitrificans & II.D.1.iv & Claus \& Berkeley (1986) \\
\hline Geobacillus thermoglucosidasius & IV.D.4.i & Suzuki et al. (1983) \\
\hline Paenibacillus alginolyticus & IV.D.1 & Nakamura (1987) \\
\hline Paenibacillus alvei & II.A.1 & Claus \& Berkeley (1986) \\
\hline Paenibacillus amylolyticus & II.D.3.iv & Nakamura (1984) \\
\hline Paenibacillus apiarius & II.D.4.i & Nakamura (1996) \\
\hline Paenibacillus azotofixans & I.A.1 & Shida et al. (1997a) \\
\hline Paenibacillus borealis & I.B.3.i & Elo et al. (2001) \\
\hline Paenibacillus chibensis & IV.B.1.iii & Shida et al. (1997b) \\
\hline Paenibacillus chondroitinus & IV.D.3.i & Nakamura (1987) \\
\hline Paenibacillus curdlanolyticus & IV.B.2.ii & Kanzawa et al. (1995) \\
\hline Paenibacillus dendritiformis & II.C.4 & Tcherpakov et al. (1999) \\
\hline Paenibacillus glucanolyticus & II.D.3.ii & Alexander \& Priest (1989) \\
\hline Paenibacillus illinoisensis & II.C.1.iii & Shida et al. (1997b) \\
\hline Paenibacillus kobensis & IV.B.2.i. $\alpha$ & Shida et al. (1997a) \\
\hline Paenibacillus koreensis & II.D.1.i & Chung et al. (2000) \\
\hline Paenibacillus larvae subsp. larvae & I.B.3.ii & Heyndrickx et al. (1996a) \\
\hline Paenibacillus larvae subsp. pulvifaciens & I.B.1.i & Heyndrickx et al. (1996a) \\
\hline Paenibacillus lautus & II.D.4.ii & Heyndrickx et al. (1996b) \\
\hline Paenibacillus macerans & II.D.1.iii & Claus \& Berkeley (1986) \\
\hline Paenibacillus macquariensis & II.C.3.iv & Priest et al. (1988) \\
\hline Paenibacillus pabuli & II.C.3.ii & Nakamura (1984) \\
\hline Paenibacillus peoriae & II.A.2 & Montefusco et al. (1993) \\
\hline Paenibacillus polymyxa & II.B.2 & Claus \& Berkeley (1986) \\
\hline Paenibacillus thiaminolyticus & II.D. 2 & Nakamura (1990) \\
\hline Paenibacillus validus & IV.D.3.ii & Nakamura (1984) \\
\hline Virgibacillus pantothenticus & II.C.3.i, II.D.3.i & Heyndrickx et al. (1999) \\
\hline Virgibacillus proomii & II.C.3.iii & Heyndrickx et al. (1999) \\
\hline
\end{tabular}

Bacillus amyloliquefaciens strains were negative by this test. Identification of these species by citrate utilization (as recommended in the key) is therefore rather probabilistic.

Another ubiquitous species is Bacillus megaterium, a representative of subgroup IV.C. Species such as Bacillus flexus and Bacillus simplex are often considered as subspecies of Bacillus megaterium (Priest et al., 1988). The newly described species Bacillus mисіlaginosus and Bacillus edaphicus were shown to be genetically close to Paenibacillus species, so they could probably be considered as representatives of this genus (Shelobolina et al., 1997).

The developed key was used for the identification of 100 bacillus strains from the UCM including some type strains and reference strains with known taxonomic positions and some newly isolated strains. The majority of the type and reference strains shown in Table 1 were identified correctly by the key, except for Paenibacillus polymyxa UCM B-5760 (the spores did not develop in swollen sporangia and anaerobic growth did not occur) and Virgibacillus pantothenticus UCM B-5907 (starch hydrolysis was negative, anaerobic growth, nitrate reduction and mannitol fermentation were positive). The strain 'Bacillus entomocidus var. subtoxicus' UCM B-5900 was identified as a member of the Bacillus cereus group (in the ATCC catalogue, this strain is listed as Bacillus thuringiensis) and 'Bacillus longissimus' UCM B-5880 was identified as Bacillus subtilis (in the VKM catalogue, this strain is listed as Bacillus sp.). Strain UCM B-5656, identified 
previously as Bacillus cereus, was identified by the key as Bacillus licheniformis. Strains UCM B-5044, 103D, 106D, 107D, 108D, 109D, 111D, 115D and 119D were isolated from the inner tissues of plants and were identified by the key as Bacillus subtilis. However, RAPD typing and 16S rRNA sequencing showed that only UCM 119D is a strain of Bacillus subtilis and all the other endophytic strains belong to Bacillus amyloliquefaciens. Another group of endophytic strains, UCM B-5908, B-5910, B-5911 and 9DT, were characterized by a very specific pattern of phenotypic properties that distinguished them from all other known Bacillus species. Analysis of the genotype of these strains confirmed their specificity and a new species, 'Bacillus endophyticus', which is represented in the key in cell III.C.4.i, has recently been proposed (Reva et al., 2001). Two strains, $1 \mathrm{r}$ and 2r, newly isolated from the soil near the destroyed reactor of the Chernobyl nuclear power station, were identified respectively as Bacillus licheniformis and Bacillus pumilus. RAPD typing and ribotyping confirmed the results of identification by the key.

A new species, 'Paenibacillus granivorans', has recently been proposed (Van der Maarel et al., 2000). The phenotypic characters provided do not distinguish this taxon from Paenibacillus curdlanolyticus (Kanzawa et al., 1995) according to our key. Unfortunately, the authors did not include this species among the reference strains in their genetic study, so it is difficult to consider the relationship between these microorganisms.

The proposed key for identification is quite practical and convenient to use, since it permits species identification on the basis of a few simple tests. For confirmation, several additional tests may be needed. An index of species of aerobic spore-forming bacteria with their addresses in the key (see Fig. 1) and references for more details is presented in Table 3.

New species are frequently described using sophisticated methods of genetics and biochemistry, but their phenotype is poorly described. Moreover, different laboratories use different sets of descriptive tests. We therefore could not include the following species in our proposed key, since they had not been characterized by the tests used in the key: 'Bacillus aminovorans' and Bacillus marinus (Rüger, 1983), 'Bacillus flavothermus' (Heinen et al., 1982), 'Bacillus macroides' (Claus \& Berkeley, 1986), Bacillus methanolicus (Arfman et al., 1992), several moderately alkaliphilic bacilli (Bacillus clausii, Bacillus gibsonii, Bacillus halmapalus, Bacillus horikoshii, Bacillus pseudoalcaliphilus and Bacillus pseudofirmus; Nielsen et al., 1995), Brevibacillus thermoruber (Manachini et al., 1985), Geobacillus subterraneus and Geobacillus uzenensis (Nazina et al., 2001) and Geobacillus thermoleovorans (Zarilla \& Perry, 1987).

The data in Table 2 are helpful for selecting useful and effective tests for the description of newly isolated strains and species. The identification key discussed above is represented in interactive mode on a website (http://www/imv.kiev.ua/key/).

\section{ACKNOWLEDGEMENTS}

The study of phenotypes and genotypes of selected strains from the UCM was undertaken at the Dept of Biological Sciences, Heriot-Watt University, Edinburgh, UK, under the guidance of and due to the contribution of Professor F. G. Priest, with financial support from the NATO linkage grant OUTR.LG 971339.

\section{REFERENCES}

Alexander, B. \& Priest, F. G. (1989). Bacillus glucanolyticus, a new species that degrades a variety of $\beta$-glucans. Int $J$ Syst Bacteriol 39, 112-115.

Andersson, M., Laukkanen, M., Nurmiaho-Lassila, E. L., Rainey, F. A., Niemelä, S. I. \& Salkinoja-Salonen, M. (1995). Bacillus thermosphaericus sp. nov., a new thermophilic ureolytic bacillus isolated from air. Syst Appl Microbiol 18, 203-220.

Aquino de Muro, M. \& Priest, F. G. (1993). Phylogenetic analysis of Bacillus sphaericus and development of an oligonucleotide probe specific for mosquito-pathogenic strains. FEMS Microbiol Lett 112, 205-210.

Arfman, N., Dijkhuizen, L., Kirchhof, G. \& 8 other authors (1992). Bacillus methanolicus sp. nov., a new species of thermotolerant, methanol-utilizing, endospore-forming bacteria. Int J Syst Bacteriol 42, 439-445.

Ash, C., Priest, F. G. \& Collins, M. D. (1993). Molecular identification of rRNA group 3 bacilli (Ash, Farrow, Wallbanks and Collins) using a PCR probe test. Proposal for the creation of a new genus Paenibacillus. Antonie Leeuwenhoek 64, 253-260.

Brousseau, R., Saint-Onge, A., Préfontaine, G., Masson, L. \& Cabana, J. (1993). Arbitrary primer polymerase chain reaction, a powerful method to identify Bacillus thuringiensis serovars and strains. Appl Environ Microbiol 59, 114-119.

Chung, Y. R., Kim, C. H., Hwang, I. \& Chun, J. (2000). Paenibacillus koreensis sp. nov., a new species that produces an iturin-like antifungal compound. Int J Syst Evol Microbiol 50, 1495-1500.

Claus, D. \& Berkeley, R. C. W. (1986). Genus Bacillus Cohn 1872 , In Bergey's Manual of Systematic Bacteriology, vol. 2, pp. 1105-1139. Edited by P. H. A. Sneath, N. S. Mair, M. E. Sharpe \& J. G. Holt. Baltimore: Williams \& Wilkins.

Demharter, W. \& Hensel, R. (1989). Bacillus thermocloaceae sp. nov., a new thermophilic species from sewage sludge. Syst Appl Microbiol 11, 272-276.

Elo, S., Suominen, I., Kämpfer, P., Juhanoja, J., Salkinoja-Salonen, M. \& Haahtela, K. (2001). Paenibacillus borealis sp. nov., a nitrogen-fixing species isolated from spruce forest humus in Finland. Int J Syst Evol Microbiol 51, 535-545.

Fortina, M. G., Pukall, R., Schumann, P., Mora, D., Parini, C., Manachini, P. L. \& Stackebrandt, E. (2001). Ureibacillus gen. nov., a new genus to accommodate Bacillus thermosphaericus (Andersson et al. 1995), emendation of Ureibacillus thermosphaericus and description of Ureibacillus terrenus sp. nov. Int $J$ Syst Evol Microbiol 51, 447-455.

Fujita, T., Shida, O., Takagi, H., Kunugita, K., Pankrushina, A. N. \& Matsuhashi, M. (1996). Description of Bacillus carboniphilus sp. nov. Int J Syst Bacteriol 46, 116-118.

Golovacheva, R. S., Loginova, L. G., Salikhov, T. A., Kolesnikov, 
A. A. \& Zaitseva, G. N. (1975). A new thermophilic species, Bacillus thermocatenulatus nov. sp. Mikrobiologiya 44, 265-268 (in Russian).

Gordon, R. E., Haynes, W. C. \& Pang, C. H.-N. (1973). Genus Bacillus. In Agricultural Handbook Number 427. Washington, DC: US Department of Agriculture.

Heinen, W., Lauwers, A. M. \& Mulders, J. W. M. (1982). Bacillus flavothermus, a newly isolated facultative thermophile. Antonie Leeuwenhoek 48, 265-272.

Heyndrickx, M., Vandemeulebroecke, K., Hoste, B., Janssen, P., Kersters, K., De Vos, P., Logan, N. A., Ali, N. \& Berkeley, R. C. W. (1996a). Reclassification of Paenibacillus (formerly Bacillus) pulvifaciens (Nakamura 1984) Ash et al. 1994, a later subjective synonym of Paenibacillus (formerly Bacillus) larvae (White 1906) Ash et al. 1994, as a subspecies of P. larvae, with emended descriptions of $P$. larvae as $P$. larvae subsp. larvae and P. larvae subsp. pulvifaciens. Int J Syst Bacteriol 46, 270-279.

Heyndrickx, M., Vandemeulebroecke, K., Scheldeman, P., Kersters, K., De Vos, P., Logan, N. A., Aziz, A. M., Ali, N. \& Berkeley, R. C. W. (1996b). A polyphasic reassessment of the genus Paenibacillus, reclassification of Bacillus lautus (Nakamura 1984) as Paenibacillus lautus comb. nov. and of Bacillus peoriae (Montefusco et al. 1993) as Paenibacillus peoriae comb. nov., and emended descriptions of $P$. lautus and of $P$. peoriae. Int J Syst Bacteriol 46, 988-1003.

Heyndrickx, M., Lebbe, L., Vancanneyt, M. \& 7 other authors (1997). A polyphasic reassessment of the genus Aneurinibacillus, reclassification of Bacillus thermoaerophilus (Meier-Stauffer et al. 1996) as Aneurinibacillus thermoaerophilus comb. nov., and emended descriptions of $A$. aneurinilyticus corrig., A. migulanus, and A. thermoaerophilus. Int $J$ Syst Bacteriol 47, 808-817.

Heyndrickx, M., Lebbe, L., Kersters, K., De Vos, P., Forsyth, G. \& Logan, N. A. (1998). Virgibacillus: a new genus to accommodate Bacillus pantothenticus (Proom and Knight 1950). Emended description of Virgibacillus pantothenticus. Int J Syst Bacteriol 48, 99-106.

Heyndrickx, M., Lebbe, L., Kersters, K., Hoste, B., De Wachter, R., De Vos, P., Forsyth, G. \& Logan, N. A. (1999). Proposal of Virgibacillus proomii sp. nov. and emended description of Virgibacillus pantothenticus (Proom and Knight 1950) Heyndrickx et al. 1998. Int J Syst Bacteriol 49, 1083-1090.

Kanzawa, Y., Harada, A., Takeuchi, M., Yokota, A. \& Harada, T. (1995). Bacillus curdlanolyticus sp. nov. and Bacillus kobensis sp. nov., which hydrolyze resistant curdlan. Int J Syst Bacteriol $\mathbf{4 5}$, 515-521.

Kuhnigk, T., Borst, E.-M., Breunig, A., König, H., Collins, M. D., Hutson, R. A. \& Kämpfer, P. (1995). Bacillus oleronius sp. nov., a member of the hindgut flora of the termite Reticulitermes santonensis (Feytaud). Can J Microbiol 41, 699-706.

Kuroshima, K., Sakane, T., Takata, R. \& Yokota, A. (1996). Bacillus ehimensis sp. nov. and Bacillus chitinolyticus sp. nov., new chitinolytic members of the genus Bacillus. Int $J$ Syst Bacteriol 46, 76-80.

Lechner, S., Mayr, R., Francis, K. P., Prüß, B. M., Kaplan, T., Wießner-Gunkel, E., Stewart, G. S. A. B. \& Scherer, S. (1998). Bacillus weihenstephanensis sp. nov. is a new psychrotolerant species of the Bacillus cereus group. Int J Syst Bacteriol 48, 1373-1382.

Manachini, P. L., Fortina, M. G., Parini, C. \& Craveri, R. (1985). Bacillus thermoruber sp. nov., nom. rev., a red-pigmented thermophilic bacterium. Int J Syst Bacteriol 35, 493-496.

Meier-Stauffer, K., Busse, H.-J., Rainey, F. A. \& 7 other authors (1996). Description of Bacillus thermoaerophilus sp. nov., to include sugar beet isolates and Bacillus brevis ATCC 12990. Int $J$ Syst Bacteriol 46, 532-541.

Montefusco, A., Nakamura, L. K. \& Labeda, D. P. (1993). Bacillus peoriae sp. nov. Int J Syst Bacteriol 43, 388-390.

Nagel, M. \& Andersen, J. R. (1991). Bacillus niacini sp. nov., a nicotinate-metabolizing mesophile isolated from soil. Int J Syst Bacteriol 41, 134-139.

Nakamura, L. K. (1984). Bacillus amylolyticus sp. nov., nom. rev., Bacillus lautus sp. nov., nom. rev., Bacillus pabuli sp. nov., nom. rev., and Bacillus validus sp. nov., nom. rev. Int J Syst Bacteriol 34, 224-226.

Nakamura, L. K. (1987). Bacillus alginolyticus sp. nov. and Bacillus chondroitinus sp. nov., two alginate-degrading species. Int J Syst Bacteriol 37, 284-286.

Nakamura, L. K. (1989). Taxonomic relationship of blackpigmented Bacillus subtilis strains and a proposal for Bacillus atrophaeus sp. nov. Int J Syst Bacteriol 39, 295-300.

Nakamura, L. K. (1990). Bacillus thiaminolyticus sp. nov., nom. rev. Int J Syst Bacteriol 40, 242-246.

Nakamura, L. K. (1993). DNA relatedness of Bacillus brevis Migula 1900 strains and proposal of Bacillus agri sp. nov., nom. rev., and Bacillus centrosporus sp. nov., nom. rev. Int J Syst Bacteriol 43, 20-25.

Nakamura, L. K. (1996). Paenibacillus apiarius sp. nov. Int J Syst Bacteriol 46, 688-693.

Nakamura, L. K. (1998). Bacillus pseudomycoides sp. nov. Int $J$ Syst Bacteriol 48, 1031-1035.

Nakamura, L. K., Blumenstock, I. \& Claus, D. (1988). Taxonomic study of Bacillus coagulans Hammer 1915 with a proposal for Bacillus smithii sp. nov. Int J Syst Bacteriol 38, 63-73.

Nazina, T. N., Tourova, T. P., Poltaraus, A. B. $\& 8$ other authors (2001). Taxonomic study of aerobic thermophilic bacilli: descriptions of Geobacillus subterraneus gen. nov., sp. nov. and Geobacillus uzenensis sp. nov. from petroleum reservoirs and transfer of Bacillus stearothermophilus, Bacillus thermocatenulatus, Bacillus thermoleovorans, Bacillus kaustophilus, Bacillus thermoglucosidasius and Bacillus thermodenitrificans to Geobacillus as the new combinations G. stearothermophilus, G. thermocatenulatus, G. thermoleovorans, G. kaustophilus, $G$. thermoglucosidasius and G. thermodenitrificans. Int J Syst Evol Microbiol 51, 433-446.

Nielsen, P., Fritze, D. \& Priest, F. G. (1995). Phenetic diversity of alkaliphilic Bacillus strains: proposal for nine new species. Microbiology 141, 1745-1761.

Niimura, Y., Koh, E., Yanagida, F., Suzuki, K., Komagata, K. \& Kozaki, M. (1990). Amphibacillus xylanus gen. nov., sp. nov., a facultatively anaerobic sporeforming xylan-digesting bacterium which lacks cytochrome, quinone, and catalase. Int J Syst Bacteriol 40, 297-301.

Nishikawa, Y., Kramer, J. M., Hanaoka, M. \& Yasukawa, A. (1996). Evaluation of serotyping, biotyping, plasmid banding pattern analysis, and HEp-2 vacuolation factor assay in the epidemiological investigation of Bacillus cereus emetic-syndrome food poisoning. Int $J$ Food Microbiol 31, 149-159.

Pettersson, B., Lembke, F., Hammer, P., Stackebrandt, E. \& Priest, F. G. (1996). Bacillus sporothermodurans, a new species producing highly heat-resistant endospores. Int J Syst Bacteriol 46, 759-764.

Priest, F. G., Goodfellow, M., Shute, L. A. \& Berkeley, R. C. W. (1987). Bacillus amyloliquefaciens sp. nov., nom. rev. Int J Syst Bacteriol 37, 69-71.

Priest, F. G., Goodfellow, M. \& Todd, C. (1988). A numerical 
classification of the genus Bacillus. J Gen Microbiol 134, 1847-1882.

Reva, O. N., Vyunitskaya, V. A., Reznik, S. R., Kozachko, I. A. \& Smirnov, V. V. (1995). Antibiotic susceptibility as a taxonomic characteristic of the genus Bacillus. Int J Syst Bacteriol 45, 409-411.

Reva, O. N., Smirnov, V. V., Pettersson, B. \& Priest, F. G. (2001). Bacillus endophyticus sp. nov., isolated from the inner tissues of cotton plants, Gossypium sp. Int J Syst Evol Microbiol 51 (in press).

Rheims, H., Frühling, A., Schumann, P., Rohde, M. \& Stackebrandt, E. (1999). Bacillus silvestris sp. nov., a new member of the genus Bacillus that contains lysine in its cell wall. Int J Syst Bacteriol 49, 795-802.

Roberts, M. S., Nakamura, L. K. \& Cohan, F. M. (1994). Bacillus mojavensis sp. nov., distinguishable from Bacillus subtilis by sexual isolation, divergence in DNA sequence, and differences in fatty acid composition. Int J Syst Bacteriol 44, 256-264.

Roberts, M. S., Nakamura, L. K. \& Cohan, F. M. (1996). Bacillus vallismortis sp. nov., a close relative of Bacillus subtilis, isolated from soil in Death Valley, California. Int J Syst Bacteriol 46, 470-475.

Rüger, H.-J. (1983). Differentiation of Bacillus globisporus, Bacillus marinus comb. nov., Bacillus aminovorans, and Bacillus insolitus. Int J Syst Bacteriol 33, 157-161.

Schlesner, H., Lawson, P. A., Collins, M. D., Weiss, N., Wehmeyer, U., Völker, H. \& Thomm, M. (2001). Filobacillus milensis gen. nov., sp. nov., a new halophilic spore-forming bacterium with Orn-D-Glu-type peptidoglycan. Int J Syst Evol Microbiol 51, 425-431.

Schloter, M., Lebuhn, M., Heulin, T. \& Hartmann, A. (2000). Ecology and evolution of bacterial microdiversity. FEMS Microbiol Rev 24, 647-660.

Scholz, T., Demharter, W., Hensel, R. \& Kandler, O. (1987). Bacillus pallidus sp. nov., a new thermophilic species from sewage. Syst Appl Microbiol 9, 91-96.

Seldin, L., Van Elsas, J. D. \& Penido, E. G. C. (1984). Bacillus azotofixans sp. nov., a nitrogen-fixing species from Brazilian soils and grass roots. Int $J$ Syst Bacteriol 34, 451-456.

Shelobolina, E. S., Avakyan, Z. A., Bulygina, E. S., Turova, T. P., Lysenko, A. M., Osipov, G. A. \& Karavaiko, G. I. (1997). Description of a new species of mucilaginous bacteria, Bacillus edaphicus sp. nov., and confirmation of the taxonomic status of Bacillus mucilaginosus Avakyan et al. 1986 based on data from phenotypic and genotypic analysis. Mikrobiologiya 66, 813-822 (in Russian).

Shida, O., Takagi, H., Kadowaki, K., Udaka, S. \& Komagata, K. (1994). Bacillus galactophilus is a later subjective synonym of Bacillus agri. Int $J$ Syst Bacteriol 44, 172-173.

Shida, O., Takagi, H., Kadowaki, K., Udaka, S., Nakamura, L. K. \& Komagata, K. (1995). Proposal of Bacillus reuszeri sp. nov., Bacillus formosus sp. nov., nom. rev., and Bacillus borstelensis sp. nov., nom. rev. Int J Syst Bacteriol 45, 93-100.

Shida, O., Takagi, H., Kadowaki, K. \& Komagata, K. (1996). Proposal for two new genera, Brevibacillus gen. nov. and Aneurinibacillus gen. nov. Int J Syst Bacteriol 46, 939-946.

Shida, O., Takagi, H., Kadowaki, K., Nakamura, L. K. \& Komagata, K. (1997a). Transfer of Bacillus alginolyticus, Bacillus chondroitinus, Bacillus curdlanolyticus, Bacillus glucanolyticus, Bacillus kobensis, and Bacillus thiaminolyticus to the genus
Paenibacillus and emended description of the genus Paenibacillus. Int J Syst Bacteriol 47, 289-298.

Shida, O., Takagi, H., Kadowaki, K., Nakamura, L. K. \& Komagata, K. (1997b). Emended description of Paenibacillus amylolyticus and description of Paenibacillus illinoisensis sp. nov. and Paenibacillus chibensis sp. nov. Int J Syst Bacteriol 47, 299-306.

Skerman, V. B. D., McGowan, V. \& Sneath, P. H. A. (editors). (1980). Approved lists of bacterial names. Int $J$ Syst Bacteriol 30, 225-420.

Spring, S., Ludwig, W., Marquez, M. C., Ventosa, A. \& Schleifer, K.-H. (1996). Halobacillus gen. nov., with descriptions of Halobacillus litoralis sp. nov. and Halobacillus trueperi sp. nov., and transfer of Sporosarcina halophila to Halobacillus halophilus comb. nov. Int J Syst Bacteriol 46, 492-496.

Stackebrandt, E. \& Goebel, B. M. (1994). Taxonomic note: a place for DNA-DNA reassociation and $16 \mathrm{~S}$ rRNA sequence analysis in the present species definition in bacteriology. Int $J$ Syst Bacteriol 44, 846-849.

Suzuki, T. \& Yamasato, K. (1994). Phylogeny of spore-forming lactic acid bacteria based on $16 \mathrm{~S}$ rRNA gene sequences. FEMS Microbiol Lett 115, 13-17.

Suzuki, Y., Kishigami, T., Inoue, K., Mizoguchi, Y., Eto, N., Takagi, M. \& Abe, S. (1983). Bacillus thermoglucosidasius sp. nov., a new species of obligately thermophilic bacilli. Syst Appl Microbiol 4, 487-495.

Takagi, H., Shida, O., Kadowaki, K., Komagata, K. \& Udaka, S. (1993). Characterization of Bacillus brevis with descriptions of Bacillus migulanus sp. nov., Bacillus choshinensis sp. nov., Bacillus parabrevis sp. nov., and Bacillus galactophilus sp. nov. Int $J$ Syst Bacteriol 43, 221-231.

Tcherpakov, M., Ben-Jacob, E. \& Gutnick, D. L. (1999). Paenibacillus dendritiformis sp. nov., proposal for a new patternforming species and its localization within a phylogenetic cluster. Int J Syst Bacteriol 49, 239-246.

Tomimura, E., Zeman, N. W., Frankiewicz, J. R. \& Teague, W. M. (1990). Description of Bacillus naganoensis sp. nov. Int J Syst Bacteriol 40, 123-125.

Van der Maarel, M. J. E. C., Veen, A. \& Wijbenga, D. J. (2000). Paenibacillus granivorans sp. nov., a new Paenibacillus species which degrades native potato starch granules. Syst Appl Microbiol 23, 344-348.

Wainø, M., Tindall, B. J., Schumann, P. \& Ingvorsen, K. (1999). Gracilibacillus gen. nov., with description of Gracilibacillus halotolerans gen. nov., sp. nov.; transfer of Bacillus dipsosauri to Gracilibacillus dipsosauri comb. nov., and Bacillus salexigens to the genus Salibacillus gen. nov., as Salibacillus salexigens comb. nov. Int J Syst Bacteriol 49, 821-831.

Wisotzkey, J. D., Jurtshuk, P. Jr, Fox, G. E., Deinhard, G. \& Poralla, K. (1992). Comparative sequence analyses on the 16S rRNA (rDNA) of Bacillus acidocaldarius, Bacillus acidoterrestris, and Bacillus cycloheptanicus and proposal for creation of a new genus, Alicyclobacillus gen. nov. Int J Syst Bacteriol 42, 263-269.

Yumoto, I., Yamazaki, K., Sawabe, T., Nakano, K., Kawasaki, K., Ezura, Y. \& Shinano, H. (1998). Bacillus horti sp. nov., a new Gram-negative alkaliphilic bacillus. Int $J$ Syst Bacteriol 48, 565-571.

Zarilla, K. A. \& Perry, J. J. (1987). Bacillus thermoleovorans sp. nov., a species of obligately thermophilic hydrocarbon utilizing endospore-forming bacteria. Syst Appl Microbiol 9, 258-264. 